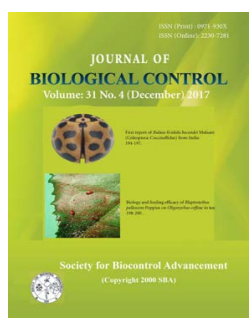

\title{
Safer management practices for Aflatoxigenic fungi in nutmeg (Myristica fragrans)
}

\author{
SALLY K. MATHEW ${ }^{1}$, K. SURENDRA GOPAL ${ }^{2 *}$, N. MINIRAJ ${ }^{3}$, ANJALY VARGHESE ${ }^{1}$ and R. JEEVA ${ }^{2}$ \\ ${ }^{I}$ Department of Plant Pathology, College of Horticulture, Kerala Agricultural University, Vellanikkara, Thrissur, Kerala, India \\ ${ }^{2}$ Department of Agricultural Microbiology, College of Horticulture, Kerala Agricultural University, Vellanikkara, Thrissur, Kerala, India \\ ${ }^{3}$ Department of Plantation crops and Spices, College of Horticulture, Kerala Agricultural University, Vellanikkara, Thrissur, Kerala, \\ India \\ *Corresponding author Email: ksurgopal@yahoo.co.in
}

\begin{abstract}
A study was undertaken to determine the presence of aflatoxigenic fungi and other fungal contaminants in the kernel, mace and shell of ripened nutmeg tree fruits collected from nutmeg plots of Ernakulam and Thrissur districts of Kerala. Mace and nut were separated from fruits and washed in tap water to remove soil particles and other debris adhering to it. The kernel, mace and shell were subjected to different chemical/botanicals by four methods viz; dipping, decoction, samples in cloth bag and fumigation in order to prevent aflatoxigenic fungi and other fungal growth during storage. Based on the present studies, it was found that pre-treatment of kernel, mace and shell of nutmeg with either citrus leaf decoction (@100 g/litre) or curry leaf decoction (@100 g/litre) or Anona seed extract (5\%) using decoction method were effective against aflatoxigenic fungi as well as fungal contamination. However, further studies are needed on pilot scale to confirm.
\end{abstract}

KEY WORDS: Aflatoxigenic fungi, botanicals, chemicals, nutmeg

(Article chronicle: Received: 25-10-2017; Revised: 26-11-2017; Accepted: 30-12-2017)

\section{INTRODUCTION}

The nutmeg tree (Myristica fragrans) is a native of Moluccas islands in East Indonesia. The tree yields two spices namely the kernel of the seed and mace covering the shell of the seed. The two common problems with nutmeg quality are hidden mold inside the nutmeg and aflatoxin contamination.

Among the various fungal contamination of spices, aflatoxin producing Aspergillus spp. are widely distributed in nature. Since, these toxins are strongly carcinogenic in humans and domestic animals, it is important to analyze foodstuffs for their presence. Aflatoxins are toxins produced by Aspergillus flavus and A. parasiticus which are considered to be serious due to their association with various diseases in human and animals, such as aflatoxicoses and liver cancer. There are four naturally occurring aflatoxins in many stored commodities, i.e. aflatoxins B1, B2, G1 and G2. The most common and toxic aflatoxin is aflatoxin B (Basappa, 2009). A study conducted on the distribution of aflatoxigenic fungi in 25 imported Indonesian nutmeg reported high levels of aflatoxins $\mathrm{B}$ and $\mathrm{G}$. The aflatoxigenic isolates were identified as Aspergillus nomius and A. bombycis and it was confirmed that these two species are mainly responsible for aflatoxin $\mathrm{G}$ contamination in nutmeg products (Kiyoshi Okano, et. al., 2012). Nutmeg imported from India, Sri Lanka, Indonesia and Brazil were infected by $A$. niger, A. flavus and Rhizopus stolonifer. The dominant fungi in these samples were $A$. flavus.

Aspergillus niger and Endomyces fibuliger were the dominant fungi in nutmeg kernels from farmers and collectors, while Endomyces repens was dominant in nutmeg samples obtained from exporters in North Sulawesi province. Aflatoxin B and total aflatoxin contents in nutmeg samples collected from farmers and exporters were relatively high. Ezekiel et al. (2013) reported that Aspergillus was the most predominant $(78.9 \%)$ genera. Of the three spices, calabash nutmeg showed the highest significant $(\mathrm{p}<0.05)$ fungal count $(3.45 \log \mathrm{CFU})$, incidence of toxigenic Aspergillus flavus $(50 \%)$ and AFB1 (50\%). Spices like calabash nutmeg are prone to contamination by moulds including toxigenic Aspergillus. Based on the literature available, it is clear that aflatoxin contamination is a problem in spices and few reports indicated the presence of Aspergillus sp. in nutmeg. 
The studies on incidence of aflatoxins in spices is scanty in Kerala particularly in nutmeg. Moreover, there are no eco-friendly or safer management practices in nutmeg to control fungal contamination as well as aflatoxin production. Hence, a study was undertaken to determine the fungal contamination and aflatoxin production in mace, kernel and shell of nutmeg during storage with an objective to prevent aflatoxigenic fungi through organic, ecofriendly and cost effective manner.

\section{MATERIALS AND METHODS}

Ripened tree split nutmeg fruits were collected from nutmeg plot in Ernakulam and Thrissur districts of Kerala. Mace and nut were separated from fruits and washed in tap water to remove soil particles and other debris adhering to it. The mace and kernel were subjected to different treatments such as chemical/botanicals by dipping, decoction, cloth bag and fumigation methods in order to prevent fungal growth during storage.

\section{Chemicals/botanicals treatment}

Desired concentrations of chemicals/botanicals were prepared. The mace and nuts were dipped separately in the solution for 10 minutes, and air dried followed by drying at $40^{\circ} \mathrm{C}$ in the hot air oven for 2-4 days and stored in a plastic containers. The treatments were $\mathrm{T}_{1}$ - potassium metabisulphate (KMS) $1 \%, \mathrm{~T}_{2}-$ sodium chloride (salt) $10 \%$, $\mathrm{T}_{3}$ - baking soda $2 \%, \mathrm{~T}_{4}$ - sodium benzoate $1 \%, \mathrm{~T}_{5}$-turmeric powder + baking soda (5:1/1litre), $\mathrm{T}_{6}$ - turmeric oil $0.2 \%, \mathrm{~T}_{7^{-}}$ asafoetida $0.1 \%, \mathrm{~T}_{8}$ - control.

\section{Decoction treatment}

Decoction of the leaves were prepared @ 100g / litre. Likewise, $10 \%$ tamarind extract and 5\% Anona seed extract were also prepared. Mace and kernel were treated separately in the decoction supernatant /extract for 10 minutes, air dried followed by drying in the hot air oven for 2-4 days and stored them in a plastic containers. The treatments were $\mathrm{T}_{1}{ }^{-}$ Citrus leaves, $\mathrm{T}_{2}$ - Curry leaves, $\mathrm{T}_{3}$ - Black pepper leaves, $\mathrm{T}_{4}$ Long pepper leaves(Piper longum), $\mathrm{T}_{5}$ - Tamarind extract, $\mathrm{T}_{6}$ - Anona seed extract (5\%), $\mathrm{T}_{7}$ - control.

\section{Cloth bag treatment}

The dried leaves were kept in muslin cloth bag @,2g/bag and kept along with properly dried mace and nut separately and stored in labeled polythene covers. The treatments were $\mathrm{T}_{1}$ - long pepper leaves (Piper longum), $\mathrm{T}_{2}$ - curry leaves, $\mathrm{T}_{3}$ citrus leaves, $\mathrm{T}_{4}$ - neem leaves, $\mathrm{T}_{5}-$ Vitex leaves, $\mathrm{T}_{6}$ - Ocimum leaves, $\mathrm{T}_{7}$ - henna leaves, $\mathrm{T}_{8}$-Aeglemarmelos leaves (Bael), $\mathrm{T}_{9}$ - cabbage leaves, $\mathrm{T}_{10}$ - turmeric rhizome bit, $\mathrm{T}_{11-}$ garlic segments, $\mathrm{T}_{12-}$ control.

\section{Fumigation treatment}

Properly dried nut and mace were fumigated for $2 \mathrm{~h}$ separately within a metal box and stored in a plastic container. The treatments were $\mathrm{T}_{1}$ - henna leaves, $\mathrm{T}_{2}$ cabbage leaves, $\mathrm{T}_{3}$ - Lantana camera leaves, $\mathrm{T}_{4}$ - long pepper leaves, $\mathrm{T}_{5}-$ Vitex leaves, $\mathrm{T}_{6}$ - neem leaves, $\mathrm{T}_{7}$ - black pepper leaves, $\mathrm{T}_{8}-$ Ocimum leaves, $\mathrm{T}_{9}-$ Leucas leaves, $\mathrm{T}_{10}$ - garlic segments, $\mathrm{T}_{11-}$ control.

Treated samples were stored separately in plastic containers /polythene covers and enumeration of the fungi were done at 6 months and 12 months after storage by serial dilution technique (Johnson and Curl, 1952). The fungal cultures obtained with different morpho-types were identified using standard protocols and sent for confirmation to a reputed laboratory of National Centre for Fungal Taxonomy (NCFT), New Delhi.

\section{RESULTS AND DISCUSSION}

The fungal population and its identity at 6 and 12 months after storage are presented below:

\section{Effect of chemicals / botanicals on the growth of fungi}

The effect of different treatments on the growth of fungi at 6 months after storage revealed that sodium chloride (salt)@10\%, baking soda@2\% and sodium benzoate (1\%) did not record any fungal growth in nut and mace indicating its effectiveness (Table 1). None of the treatments showed fungal growth on mace, while, potassium meta bisulphate (KMS) $1 \%$ and turmeric powder + baking soda (5:1/1litre) showed single colony of Aspergillus sp. on shell and kernel respectively. Similarly, potassium meta-bisulphate (KMS) (1\%), and turmeric oil $(0.2 \%)$ recorded Penicillium sp. on kernel. However, kernel and mace of control samples showed Aspergillus spp. and 3 colonies of Phytophthora on shell. The highest fungal population was recorded in the case of control $\left(3-28 \times 10^{3} \mathrm{cfu} / \mathrm{g}\right)$. The highest population of fungi was in the case of kernel $\left(28 \times 10^{3} \mathrm{cfu} / \mathrm{g}\right)$ followed by mace $\left(11 \times 10^{3} \mathrm{cfu} / \mathrm{g}\right)$.

Sodium benzoate (1\%) was the most effective among the treatments at 12 months after storage. There were no fungal growth on mace, kernel and shell. The highest fungal population was recorded in samples treated with $0.2 \%$ turmeric $\left(\mathrm{T}_{6}\right)$ and lowest number was found in samples treated with $1 \%$ potassium meta-bisulphate $\left(\mathrm{T}_{1}\right)$. The fungus identified were Aspergillus niger, A. oryzae, A.ochraceous, A. flavus, Acremonium kiliense, Penicillium 
citrinum and Syzgytes sp. novo. However, among the treatments, sodium benzoate $(1 \%)$ was the most effective in preventing the growth of fungi in nutmeg. Even though, A. flavus was recorded, but it does not produce aflatoxin in nutmeg. The aflatoxin in nutmeg is produced either by Aspergillus nomius and A. bombycis. (Kiyoshi Okano, et. $a l ., 2012$ ) Since, such fungi were not found in the present studies, it may be presumed that there was no aflatoxin in nutmeg samples. Most of the fungi recorded in the samples were A. ochraceous.

\section{Effect of different leaf extract on the growth of fungi}

The effect of leaf decoction on the growth of fungi at 6 MAS revealed that all the treatments were effective as none of them recorded fungal growth on kernel, mace and shell (Table 2). The treatments did not show any fungal growth in kernel, shell and mace of the nutmeg except control indicating the effectiveness of leaf decoction. However, the highest fungal population was recorded in the case of control $\left(\mathrm{T}_{8}\right)$ with fungal population of 3 to 28 x $10{ }^{3} \mathrm{cfu} / \mathrm{g}$. The kernel $\left(28\right.$ x $\left.10{ }^{3} \mathrm{cfu} / \mathrm{g}\right)$ recorded highest population followed by mace $\left(11 \times 10{ }^{3} \mathrm{cfu} / \mathrm{g}\right)$ in control and Aspergillus sp. was predominant in kernel and mace, whereas, Phytophthora was noticed on shell. These results indicate that there were no aflatoxin producing fungi but only general fungi in nutmeg.

At 12 MAS, citrus leaves, curry leaves andanona seed extract $(5 \%)$ were effective as there was no fungal growth. The highest fungal population were recorded in long pepper leaves and Penicillium citrinum, Aspergillus oryzae and Alternaria alternata were the major contaminants. However, black pepper leaves and tamarind extract (10\%) showed less fungal population and the fungi identified were A. oryzae and Al. alternate. The citrus leaves, curry leaves and anona seed extract $(5 \%)$ were effective in preventing the growth of fungus when compared with other treatments. In a similar study, Maruti, et.al. (2011) reported that citrus peel oils had strong antimicrobial activity against Pseudomonas aeruginosa (NCIM 2036) with methanol as solvent, Salmonella typhimurium (NCIM 5021) in the presence of acetone. It is well known that citrus flavonoids have a broad spectrum of biological activity including antibacterial, antifungal, anti-diabetic, anticancer and antiviral activities.

Table 1. Effect of chemicals and botanicals on the fungal growth in kernel, shell and mace of nutmeg at 6 and 12 months after storage (MAS)

\begin{tabular}{|c|c|c|c|c|c|c|}
\hline \multirow[t]{3}{*}{ Treatments } & \multicolumn{6}{|c|}{ Fungal Population (x $\left.10^{3} \mathrm{cfu} / \mathrm{g}\right)$} \\
\hline & \multicolumn{3}{|l|}{$6 \mathrm{MAS}$} & \multicolumn{3}{|l|}{$12 \mathrm{MAS}$} \\
\hline & Kernel & Shell & Mace & Kernel & Shell & Mace \\
\hline $\begin{array}{l}\mathrm{T}_{1}(1 \% \text { Potas- } \\
\text { sium mono } \\
\text { sulphate })\end{array}$ & $\begin{array}{l}1 \\
\text { (Penicillium sp.) }\end{array}$ & 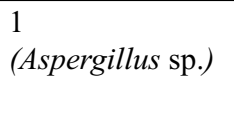 & 0 & $\begin{array}{l}0.5 \\
\text { (Aspergillus } \\
\text { oryzae) }\end{array}$ & Absent & $\begin{array}{l}0.5 \\
\text { (Aspergillus } \\
\text { niger) }\end{array}$ \\
\hline $\begin{array}{l}\mathrm{T}_{2}(10 \% \text { Sodium } \\
\text { chloride Salt }),\end{array}$ & 0 & 0 & 0 & Absent & Absent & $\begin{array}{l}8.5 \\
\text { (Aspergillus } \\
\text { ochraceous } \\
\text { and } \\
\text { Penicillium } \\
\text { citrinum) }\end{array}$ \\
\hline $\begin{array}{l}\mathrm{T}_{3}(2 \% \text { Baking } \\
\text { Soda })\end{array}$ & 0 & 0 & 0 & Absent & $\begin{array}{l}1 \\
\text { (Acremonium } \\
\text { kiliense) } \\
\end{array}$ & $\begin{array}{l}3 \\
\text { (Aspergillus } \\
\text { flavus) }\end{array}$ \\
\hline $\begin{array}{l}\mathrm{T}_{4}(1 \% \text { Sodium } \\
\text { benzoate })\end{array}$ & 0 & 0 & 0 & Absent & $\begin{array}{l}\text { Nil } \\
\text { Absent }\end{array}$ & Nil \\
\hline $\begin{array}{l}\mathrm{T}_{5} \text { (Turmeric } \\
\text { Powder + Baking } \\
\text { soda(5:1/1litre) }\end{array}$ & $\begin{array}{l}1 \\
\text { (Aspergillus sp.) }\end{array}$ & 0 & 0 & $\begin{array}{l}1.5 \\
\text { (Aspergillus } \\
\text { ochraceous) }\end{array}$ & $\begin{array}{l}0.5 \\
\text { (Aspergillus } \\
\text { ochraceous) }\end{array}$ & $\begin{array}{l}0.5 \\
\text { (Aspergillus } \\
\text { niger) }\end{array}$ \\
\hline $\begin{array}{l}\mathrm{T}_{6}(0.2 \% \text { Tur- } \\
\text { meric oil })\end{array}$ & $\begin{array}{l}2 \\
\text { (Penicillium sp) }\end{array}$ & 0 & 0 & $\begin{array}{l}95.5 \\
\text { (Aspergillus } \\
\text { ochraceous) } \\
\end{array}$ & $\begin{array}{l}127 \\
\text { (Aspergillus } \\
\text { ochraceous) }\end{array}$ & $\begin{array}{l}0.5 \\
\text { (Aspergillus } \\
\text { ochraceous) }\end{array}$ \\
\hline $\begin{array}{l}\mathrm{T}_{7}(0.1 \% \text { Asa- } \\
\text { foetida })\end{array}$ & 0 & 0 & 0 & Absent & 0.5 & $\begin{array}{l}1 \\
\text { (Syzgytes } \\
\text { sp.novo) }\end{array}$ \\
\hline $\mathrm{T}_{8}$ (Control) & $\begin{array}{l}28 \\
\text { (Aspergillus sp.) }\end{array}$ & $\begin{array}{l}3 \\
\text { (Phytopthora sp.) }\end{array}$ & $\begin{array}{l}11 \\
\text { (Aspergillus } \mathrm{sp} . \text { ) }\end{array}$ & & & \\
\hline
\end{tabular}

( ) Indicate the fungus present in the samples 
Table 2. Effect of different leaf extract on the growth of fungi in kernel, shell and mace of nutmeg at 6 and 12 months after storage (MAS)

\begin{tabular}{|c|c|c|c|c|c|c|}
\hline \multirow{3}{*}{ Treatments } & \multicolumn{6}{|c|}{ Fungal Population $\left(10^{3} \mathrm{cfu} / \mathrm{g}\right)$} \\
\hline & \multicolumn{3}{|c|}{6 MAS } & \multicolumn{3}{|c|}{12 MAS } \\
\hline & Kernel & Shell & Mace & Kernal & Shell & Mace \\
\hline $\mathrm{T}_{1}$ (Citrus leaves) & 0 & 0 & 0 & 0 & 0 & 0 \\
\hline $\mathrm{T}_{2}$ (Curry leaves & 0 & 0 & 0 & 0 & 0 & 0 \\
\hline $\begin{array}{l}\mathrm{T}_{3}(\text { Black Pepper } \\
\text { Leaves }\end{array}$ & 0 & 0 & 0 & 0 & $\begin{array}{l}1.5 \\
\text { (Aspergillus } \\
\text { oryzae } \\
\text { and Alternaria } \\
\text { alternata) }\end{array}$ & 0 \\
\hline $\begin{array}{l}\mathrm{T}_{4} \text { (Long pepper- } \\
\text { leaves) }\end{array}$ & 0 & 0 & 0 & $\begin{array}{l}7 \text { (Penicillium } \\
\text { citrinum) }\end{array}$ & $\begin{array}{l}89 \\
\text { (Aspergillus } \\
\text { oryzae } \\
\text { and Alternaria } \\
\text { alternata) }\end{array}$ & 0 \\
\hline $\begin{array}{l}\mathrm{T}_{5}(\text { Tamarind } \\
\text { extract }(10 \%)\end{array}$ & 0 & 0 & 0 & $\begin{array}{l}16 \\
\text { (Aspergillus } \\
\text { oryzae) }\end{array}$ & 0 & 0 \\
\hline $\begin{array}{l}\mathrm{T}_{6} \text { (Anona Seed } \\
\text { extract }(5 \%)\end{array}$ & 0 & 0 & 0 & 0 & 0 & 0 \\
\hline $\mathrm{T}_{7}($ Control $)$ & $\begin{array}{l}28 \\
\text { (Aspergillus sp.) }\end{array}$ & $\begin{array}{l}3 \\
\text { (Phytophthora sp.) }\end{array}$ & $\begin{array}{l}11 \\
\text { (Aspergillus sp.) }\end{array}$ & & & 0 \\
\hline
\end{tabular}

( ) Indicate the fungus present in the samples

In the present studies, citrus leaf were used and it showed antifungal activity against stored nutmeg. In the case of curry leaves, it was found effective against aflatoxigenic fungi as no growth of such fungi were observed. Manisha et al. (2011) reported that curry leaf is commonly used against diarrhea, dysentery and to prevent vomiting, as it is a rich source of carbazole alkoids, carbohydrates, steroids and flavonoids It also showed some antimicrobial activity as well as antifungal activity. In the present studies, curry leaf was effective in preventing the growth of aflatoxin producing fungi in stored nutmeg. Annona squamosa was also effective against the fungal growth in present studies. Vidyasagar and Shivakumar (2012) reported that plant of A. squamosa are antimutagenic, anthelminthic, scavenging, antidiabetic, hepatoprotective, anti-thyroid, anti-genotoxic, antiplasmodial, molluscicidal, analgesic activities and antimicrobial activity which is in agreement with the present studies. In a similar studies, Koushik et al. (2017) also reported that the extracts of $A$. squamosa (L) and Manilkara zapota (L.) could be considered as potential sources of antifungal compounds for treating fungal infections. The extracts exhibited antifungal activity, even at very lower concentrations. In the present studies, Annona seed extract were effective against aflatoxin producing fungi on stored nutmeg.

\section{Effect of leaves on the growth of fungi}

All the treatments with leaves under fumigation were effective than control (Table 3). There were no Aspergillus in the nutmeg samples treated with long pepper leaves, curry leaves, neem leaves and vitex leaves. The curry leaves $\left(\mathrm{T}_{2}\right)$ and long pepper leaves $\left(\left(\mathrm{T}_{1}\right)\right.$ recorded Penicillium and Phytophthora. No fungal growth was observed in kernel and shell treated with citrus leaves $\left(\mathrm{T}_{3}\right)$, neem leaves $\left(\mathrm{T}_{4}\right)$ and vitex leaves $\left(\left(\mathrm{T}_{5}\right)\right.$, whereas Phytophthora $\mathrm{sp}$. was recorded in the mace. However, control samples recorded highest number of Aspergillus sp. ( $\left.7 \times 10^{3} \mathrm{cfu} / \mathrm{g}\right)$ on mace followed by kernel and shell. Moreover, Phytophthora infection was also noticed on mace and kernel. Among the treatments, nutmeg treated with dried leaves of citrus, neem and vitex were effective at 6 MAS.

No fungal growth was found in nutmeg samples treated with citrus leaves $\left(\mathrm{T}_{3}\right)$, Vitex leaves $\left(\mathrm{T}_{5}\right)$, Aegelmarmalos leaves (bael) $\left(\mathrm{T}_{8}\right)$ and turmeric rhizome bit $\left(\mathrm{T}_{10}\right)$ at 12 MAS. Highest population of number of fungal colonies were found in samples treated with long pepper leaves $\left(\mathrm{T}_{1}\right)$, curry leaves $\left(\mathrm{T}_{2}\right)$, henna leaves $\left(\mathrm{T}_{7}\right)$ and garlic segments $\left(\mathrm{T}_{11}\right)$. At 12 months after storage, Aspergillus niger, $A$. ochraceous, Penicillium citrinum, Acremonium alternatum, Eurotium amestaldomi, A. nidulans were the major fungus identified. Eventhough, Aspergillus ochraceous was found 
Table 3. Effect of different leaves in a cloth bag on the growth of fungi in kernel, shell and mace of nutmeg at 6 and 12 MAS

\begin{tabular}{|c|c|c|c|c|c|c|}
\hline \multirow{3}{*}{ Treatments } & \multicolumn{6}{|c|}{ Fungal Population $\left(\mathrm{x} 10^{3} \mathrm{cfu} / \mathrm{g}\right)$} \\
\hline & \multicolumn{3}{|c|}{$6 \mathrm{MAS}$} & \multicolumn{3}{|l|}{$12 \mathrm{MAS}$} \\
\hline & Kernel & Shell & Mace & Kernal & Shell & Mace \\
\hline $\begin{array}{l}\text { T1(Long pepper } \\
\text { leaves) }\end{array}$ & $\begin{array}{l}3 \\
\text { (Phytophthora sp.) }\end{array}$ & $\begin{array}{l}1 \\
\text { (Phytophthora sp.) }\end{array}$ & 0 & $\begin{array}{l}4 \\
\text { (Aspergillus } \\
\text { niger) }\end{array}$ & $\begin{array}{l}0.5 \\
\text { (Aspergills } \\
\text { niger) }\end{array}$ & Nil \\
\hline $\mathrm{T}_{2}$ (Curry leaves) & $\begin{array}{l}2 \\
\text { (Phytophthora sp.) }\end{array}$ & 0 & $\begin{array}{l}3 \\
\text { (Penicillium sp.) }\end{array}$ & $\begin{array}{l}3 \\
\text { (Aspergillus } \\
\text { niger) }\end{array}$ & Nil & $\begin{array}{l}1 \\
\text { (Aspergills } \\
\text { ochraceous) }\end{array}$ \\
\hline $\mathrm{T}_{3}$ (Citrus leaves) & 0 & 0 & $\begin{array}{l}1 \\
\text { (Phytophthora sp.) }\end{array}$ & Nil & Nil & Nil \\
\hline $\mathrm{T}_{4}$ (Neem leaves $)$ & 0 & 0 & $\begin{array}{l}1 \\
\text { (Phytophthora sp.) }\end{array}$ & $\begin{array}{l}2 \\
\text { (Acremonium } \\
\text { strictum } \\
\text { and } \\
\text { Acremonium } \\
\text { sp. novo) }\end{array}$ & Nil & Nil \\
\hline $\mathrm{T}_{5}$ (Vitex leaves) & 0 & 0 & $\begin{array}{l}1 \\
\text { (Phytophthora sp.) }\end{array}$ & Nil & Nil & Nil \\
\hline $\begin{array}{l}\mathrm{T}_{6}(\text { Ocimum } \\
\text { leaves })\end{array}$ & 0 & $\begin{array}{l}1 \\
\text { (Aspergillus sp.) }\end{array}$ & 0 & $\begin{array}{l}0.5 \\
\text { (Aspergillus } \\
\text { sclerotium) }\end{array}$ & Nil & Nil \\
\hline $\mathrm{T}_{7}$ (Henna leaves) & $\begin{array}{l}2 \\
\text { (Aspergillus sp.) }\end{array}$ & 0 & 0 & 1 & $\begin{array}{l}0.5 \\
\text { (Aspergillus } \\
\text { niger) }\end{array}$ & $\begin{array}{l}2.5 \\
\text { (Penicillium- } \\
\text { citrinum) }\end{array}$ \\
\hline $\begin{array}{l}\mathrm{T}_{8}(\text { Aeglemar- } \\
\text { mlosleaves }(\mathrm{Bael})\end{array}$ & $\begin{array}{l}2 \\
\text { (Phytophthora sp.) }\end{array}$ & $\begin{array}{l}2 \\
\text { (Aspergillus sp.) }\end{array}$ & $\begin{array}{l}3 \\
\text { (Aspergillus sp.) }\end{array}$ & Nil & Nil & Nil \\
\hline $\begin{array}{l}\mathrm{T}_{9}(\mathrm{Cabbage} \\
\text { leaves })\end{array}$ & $\begin{array}{l}3 \\
\text { (Phytophthora sp.) } \\
1 \\
\text { (Aspergillus sp.) } \\
1 \\
\text { (Penicillium sp.) }\end{array}$ & $\begin{array}{l}3 \\
\text { (Phytophthora sp.) } \\
1 \\
\text { (Phytophthora } \mathrm{sp} .)\end{array}$ & $\begin{array}{l}1 \\
\text { (Aspergillus sp.) }\end{array}$ & $\begin{array}{l}0.5 \\
\text { (Penicillium } \\
\text { citrinum) }\end{array}$ & Nil & Nil \\
\hline $\begin{array}{l}\mathrm{T}_{10} \text { (Turmeric } \\
\text { rhizome bit) }\end{array}$ & $0^{\prime}$ & $\begin{array}{l}1 \\
\text { (Aspergillus sp.) }\end{array}$ & $\begin{array}{l}2 \\
\text { (Aspergillus sp.) }\end{array}$ & Nil & Nil & Nil \\
\hline $\begin{array}{l}\mathrm{T}_{11} \text { (Garlic seg- } \\
\text { ments) }\end{array}$ & $\begin{array}{l}2 \\
\text { (Phytophthora sp.) }\end{array}$ & $\begin{array}{l}1 \\
\text { (Aspergillus sp.) } \\
1 \\
\text { (Phytophthora sp.) }\end{array}$ & $\begin{array}{l}2 \\
\text { (Aspergillus sp.) }\end{array}$ & Nil & Nil & $\begin{array}{l}13 \\
\text { (Aspergills- } \\
\text { nidulans } \\
\text { and } \\
\text { Penicillum } \\
\text { citrinum) } \\
\end{array}$ \\
\hline $\mathrm{T}_{12}$ Control & $\begin{array}{l}28 \\
\text { (Aspergillus sp.) }\end{array}$ & $\begin{array}{l}3 \\
\text { (Phytophthora sp.) }\end{array}$ & $\begin{array}{l}11 \\
\text { (Aspergillus sp.) }\end{array}$ & & & \\
\hline
\end{tabular}

( ) Indicate the fungus present in the samples

in the sample, it is not reported to be aflatoxigenic fungi in nutmeg. However, lowest number of colonies were seen in the case of neem leaves (T4) and the fungus found were Acremonium strictum and Acremonium sp.novo. In a similar study, Dharmaputra et. al., (2015) reported that the dominant fungi in nutmeg samples from farmers were Penicillium citrinum(81\%) followed by A. niger(69\%) and Eurotium repens $(63 \%)$ whereas nutmegs collected from collectors were Endomyces fibuliger (76\%), A. niger (76\%) and $P$. citrinum (76\%) which might have been due to high moisture content. In the present studies, similar fungi were recorded which is in agreement with the earlier studies.

\section{Effect of fumigation of leaves on the growth of fungi}

All the treatments were effective except for ocimum (Table 4.). There were no fungal growth in samples fumigated 
Table 4. Effect of fumigation of leaves on the growth of fungi in kernel, shell and mace of nutmeg at 6 and 12 MAS

\begin{tabular}{|c|c|c|c|c|c|c|}
\hline \multirow{3}{*}{ Treatments } & \multicolumn{6}{|c|}{ Fungal Population (x 10 $\left.10^{3} \mathrm{cfu} / \mathrm{g}\right)$} \\
\hline & \multicolumn{3}{|c|}{$6 \mathrm{MAS}$} & \multicolumn{3}{|l|}{$12 \mathrm{MAS}$} \\
\hline & Kernel & Shell & Mace & Kernal & Shell & Mace \\
\hline $\mathrm{T}_{1}$ (Henna leaves) & $\begin{array}{l}2 \\
\text { (Phytophthora sp) }\end{array}$ & 0 & 0 & Nil & $\begin{array}{l}1 \\
\text { (Alternaria } \\
\text { alternata) }\end{array}$ & Nil \\
\hline $\mathrm{T}_{2}$ (Cabbage leaves) & 0 & 0 & 0 & Nil & Nil & $\begin{array}{l}\text { (Alternaria } \\
\text { alternate } \\
\text { and As- } \\
\text { pergillus } \\
\text { oryzae) }\end{array}$ \\
\hline $\begin{array}{l}\mathrm{T}_{3} \text { (Lantana camera } \\
\text { leaves) }\end{array}$ & 0 & 0 & 0 & Nil & Nil & $\begin{array}{l}232.5 \\
\text { (Aspergillus } \\
\text { nidulans) }\end{array}$ \\
\hline $\begin{array}{l}\mathrm{T}_{4} \text { (Long pepper } \\
\text { thippali) }\end{array}$ & 0 & 0 & 0 & $\begin{array}{l}0.5 \\
\text { (Alternaria } \\
\text { alternata) }\end{array}$ & Nil & Nil \\
\hline $\mathrm{T}_{5}$ (Vitex leaves) & & & & $\begin{array}{l}1.5 \\
\text { (Aspergil- } \\
\text { lussclerotium) }\end{array}$ & $\begin{array}{l}0.5 \\
\text { (Aspergills } \\
\text { sclerotium) } \\
\end{array}$ & $\begin{array}{l}2 \\
\text { (Aspergillus } \\
\text { niger) }\end{array}$ \\
\hline $\mathrm{T}_{6}($ Neem leaves $)$ & 0 & 0 & 0 & Nil & Nil & $\begin{array}{l}1 \\
\text { (Aspergillus } \\
\text { sclerotium) }\end{array}$ \\
\hline $\begin{array}{l}\mathrm{T}_{7} \text { (Black pepper } \\
\text { leaves) }\end{array}$ & 0 & 0 & 0 & Nil & Nil & Nil \\
\hline $\mathrm{T}_{8}($ Ocimum leaves $)$ & $\begin{array}{l}2 \\
\text { (Aspergillus sp.) } \\
1 \\
\text { (Penicillium } \mathrm{sp} .) \\
5 \\
\text { (Phytophthora sp.) }\end{array}$ & $\begin{array}{l}3 \\
(\text { Aspergillus } \mathrm{sp} .) \\
2 \\
(\text { Penicillium } \mathrm{sp} .) \\
2 \\
\text { (Phytophthora } \mathrm{sp} .)\end{array}$ & $\begin{array}{l}1 \\
\text { (Aspergillus sp.) } \\
8 \\
\text { (Phytophthora } \mathrm{sp} .)\end{array}$ & $\begin{array}{l}3.5 \\
\text { (Aspergillus } \\
\text { sclerotium) }\end{array}$ & Nil & Nil \\
\hline $\mathrm{T}_{9}$ (Leucas leaves) & 0 & 0 & 0 & Nil & Nil & Nil \\
\hline $\begin{array}{l}\mathrm{T}_{10} \text { (Garlic seg- } \\
\text { ments) }\end{array}$ & 0 & 0 & 0 & Nil & 0.5 & $\begin{array}{l}2.5 \\
\text { (Aspergillus } \\
\text { sclerotium) } \\
\end{array}$ \\
\hline $\mathrm{T}_{11}($ Control $)$ & $\begin{array}{l}28 \\
\text { (Aspergillus sp.) }\end{array}$ & $\begin{array}{l}3 \\
\text { (Phytophthora sp.) }\end{array}$ & $\begin{array}{l}11 \\
\text { (Aspergillus sp.) }\end{array}$ & Nil & 0.5 & $\begin{array}{l}1.5 \\
\text { (Aspergillus } \\
\text { niger) }\end{array}$ \\
\hline
\end{tabular}

( ) Indicate the fungus present in the samples

with cabbage leaves, Lantana camera leaves, long pepper leaves, Vitex leaves, neem leaves, black pepper leaves, Leucas leaves and Garlic pieces. Aspergillus sp. were noticed in all the types of samples fumigated with Ocimum. Henna treated samples showed Phytophthora growth on kernel. . However, control samples showed maximum colonies of Aspergillus ( 7 $\mathrm{x} 10^{3} \mathrm{cfu} / \mathrm{g}$ ) on mace followed by kernel and shell. In addition, Phytophthora sp. infection was also noticed on mace and kernel. All the treatments except for Ocimum and henna leaves were most effective in the management of fungal growth after 6 MAS.

Highest fungal population at 12 MAS was in the samples treated with Lantana camera leaves and the fungus identified was Aspergillus nidulans from mace. Minimum fungal population was recorded in treatments with henna leaves, cabbage leaves, long pepper leaves, vitex leaves, neem leaves, ocimum leaves and garlic segments. Major fungus identified in these treatments were Alternaria alternata, Aspergillus oryzae, A. sclerotium, and A nidulans. Black pepper leaves $\left(\mathrm{T}_{7}\right)$ and Leucas leaves $\left(\mathrm{T}_{9}\right)$ were most effective among the treated nutmeg samples.

\section{CONCLUSION}

Based on the present studies, it may be concluded that pretreatment of mace and nut of nutmeg with citrus leaf decoction (@100 g/litre) or curry leaf decoction (@100 g/litre) or Anona 
seed extract (5\%) using decoction method were effective against fungal contamination as well as aflatoxigenic fungi. However, further studies are needed on pilot scale to confirm.

\section{ACKNOWLEDGEMENT}

The authors are grateful to the State Planning Board, Government of Kerala, for providing funds to carry out this research work. The facilities provided by College of Horticulture, KAU is acknowledged.

\section{REFERENCES}

Basappa SC. 2009. Aflatoxins: Formation, Analysis and Control. Alpha Science International, Oxford. PMCid:PMC2814305.

Ezekiel CN, Fapohunda SO, Olorunfemi MF, Oyebanji AO, Obi I. 2013. Mycobiotica and aflatoxin B1 contamination of Piper guineense (Ashanti pepper), Piper nigrum (black pepper) and Monodora myristica (calabash nutmeg) from Lagos, Nigeria. Int food Res $J$. 20: $111-116$.

Okano K, Tomita T, Ohzu Y, Takai M, Ose A, Kotsuka A, Ikeda N, Sakata J, Kumeda Y, Nakamura N, Ichinoe M. 2012. Aflatoxins $\mathrm{B}$ and $\mathrm{G}$ contamination and aflatoxigenic fungi in nutmeg. Shokuhin Eiseigaku Zasshi 53(5): 211-216. Crossref PMid:23154760.

Vats M, Singh H, Sardana S. 2011. Antimicrobial activity of curry leaves and papaya leaves against pathogenic strains. Brazilian J Microbiol. 42(4): 1517-8382.

Maruti J, Dhanavade, Chidamber B, Jalkute, Ghosh JS, Sonawane KD. 2011. Study Antimicrobial Activity of Lemon (Citrus lemon L.) Peel Extract. Br J Pharmacol. 2(3): 119-122.

Setyawati O, Dharmaputra, Santiambarwati, Retnowati I, Nurfadila N. 2015. Fungal infection and aflatoxin contamination in stored nutmeg (Myristica fragrans) kernels at various stages of delivery chain in north Sulawesi province. BIOTROPIA 22(2): 129.

Koushik OS, Srinivasa Babu P, Karthikeyan R. 2017. Phyto chemical screening and evaluation of antifungal activity on the seed extracts of Annona squamosa (L) and Manilkara zapota (L.) CIBTech J Biotech 2319-3859: (online) (1) pp. 8-11.

Vidyasagar GM, Shivakumar Singh P. 2012. A comparative antimicrobial activity of methanolic root, leaf, seed cotyledon extracts of Annona squamosa L. International J Pharmacol Pharmaceutical Sci. 4(5): 289-292. 